\title{
MUSLIM RESPONSES TO THE CRUSADES - An Analysis of the Muslim Ideological, Military, and Diplomatic Responses to the Medieval Christian Crusades -
}

\author{
Mohd Yaseen Gada \\ Aligarb Muslim University, Aligarh-India \\ E-mail: myaseengada.rs@amu.ac.in
}

\begin{abstract}
Muslim responses to the Crusades have been a focus of modern scholarship in both Crusades studies and medieval Islamic history over the last decade or so. This important aspect of the Crusades had been largely, if not entirely, ignored by Western scholars owing to their particular Western academic environment. One of the common misconceptions about the Muslim understanding of and response to the Crusaders is the view that the Muslims knew little, if anything, about them and were confused about the difference between the Byzantines and the Franks (Crusaders). Consequently, it took the Muslims approximately a half century to organize a unified Muslim front to fight against the Crusaders. Despite this view, Muslim sources reveal that Muslim intellectuals and religious figures closely observed the Crusaders' actions and motives, and they did, in various ways, respond to this hitherto unimagined flood of people from the West. This paper attempts to highlight and explore the Muslim ideological, religious, military, and diplomatic responses to the Crusaders.
\end{abstract}

Key Words: Muslim response, Crusades, crusaders, jihād, al-Sulamī

Ilahiyat Studies

Volume 6 Number 2 Summer / Fall 2015 


\section{Introduction}

What happened when the Islamic world was being invaded by an external enemy, the Latins (Crusaders), near the end of the eleventh century? Were the Muslims so preoccupied and obsessed with their internal problems that they did not think to resist the invaders? The answer would be no! Muslims responded to this wave of Christians. First and foremost, Muslim religious and intellectual elites and those who had a direct confrontation with the Franks, as in the case of Anatolia, resisted to the best of their ability. Carole Hillenbrand, in her groundbreaking The Crusades: Islamic Perspective, concedes that "it would be wrong to assume that there were no stirrings of jiha a d feelings" ${ }^{1}$ among the Muslims especially after the Franks took Jerusalem in 1099. The Muslim calls to military jiba $\bar{a} d$ even predate the fall of Jerusalem; quoting Ibn al-Jawzī's record for the year 1097-1098, Hillenbrand writes, "There were many calls to go out and fight against the Franks and complaints multiplied in every place." ${ }^{2}$ However, it is wrong to assume that Muslims were completely indifferent to practicing the doctrine of jiha $\bar{a} d$ and did not resist the Frankish invasion from the beginning. To make things much easier to understand, we would like to divide the Muslim response into three broad categories: the ideological/intellectual/religious, the military, and the diplomatic.

\section{The Ideological/Intellectual/Religious Response}

The fall of Jerusalem was a disastrous event recorded with great sadness and pain. Al-Masjid al-aqșā and the Dome of the Rock have always been a glorious sight and potent symbol of the Islamic faith. The Frankish occupation of Jerusalem, which housed both of those buildings, was an act of grave desecration in Muslim eyes. Moreover, symbols of pollution and purity abound in the Muslim portrayal of the Franks. Muslims often recalled, "If Mecca was the body of faith, then Medina was one wing and Jerusalem was the other." Therefore, the implication was clear, writes Michael Foss, that "For the progress of the whole faith both wings were needed. After the fall of Jerusalem, there was an expectation within Islam that the disaster

\footnotetext{
1 Carole Hillenbrand, The Crusades: Islamic Perspective (Edinburgh: Edinburgh University Press, 1999), 104.

2 Ibid., 78.
} 
would be soon reversed." ${ }^{3}$ The Muslim problem, however, was that of the internal discord, especially strife among the rulers. In such a milieu, the first focus for any call to $j i h \bar{a} d$ or resistance against the enemy rested with the Sunnī caliph in Baghdad, al-Mustazhir (d. 512/1118). It was certainly he who was expected to take responsibility for the promotion of a $j i \bar{a} \bar{d}$ in the defense of Islam, the Muslim heartlands and the people.

Thus, the chief $q \bar{a} d \bar{\imath}$ (or Muslim religious leader), Abū Șacd alHarawi (d. ca. 500/1106), of Damascus in Syria led a delegation to the Caliph in Baghdad, and on a Friday in August 1099 C.E. he preached a sermon that brought tears to every eye present in the Great Masjid of Baghdad. He wanted help in encouraging the fight against the "Frankish" armies of the First Crusade. ${ }^{4}$

Muslim preachers travelled throughout the 'Abbāsid caliphate proclaiming the tragedy and rousing men to recover al-Masjid al-aqșā, which Muslims believed to be the place of the Prophet Muhammad's heavenly ascension, from infidel hands. However, the Caliph, alMustazhir, could not provide enough help to be of use, and thus alHarawi returned in failure. Only a handful of Muslim scholars and intellectuals, including some prominent poets, could stir passions in the manner that Sir Muhammad Iqbāl was able to do in the twentieth century, another time of despair for the Muslim community, writes M. J. Akbar. ${ }^{5}$ Famous poets often raised their voices, fiercely reminding Muslim rulers, preoccupied with internal discord and negligence, of their duty. Abū 1-Muzaffar al-Abīwardī was living in Baghdad when al-Qāọī al-Harawī sought the Caliph's help. ${ }^{6}$

3 Michael Foss, People of the First Crusade: The Truth about the Christian-Muslim War Revealed (New York: Arcade Publishing, 1997), 182.

4 Abū l-Ḥasan 'Izz al-Dīn 'Alī ibn Muhammad ibn Muhammad Ibn al-Athīr alShaybānī al-Jazarī, The Chronicle of Ibn Al-Athīr for the Crusading Period from al-Kamil fi'l-Ta'rīkh, Part I: The Years 491-541/1097-1146: The Coming of the Franks and the Muslim Response (translated by D. S. Richards; Farnham, England: Ashgate, 2010), 22.

5 M. J. Akbar, The Shade of Swords: Jihad and the Conflict between Islam and Christianity (London \& New York: Routledge, 2002), 71.

6 Ibn al-Athìr quotes the lament of the Iraqi poet, al-Abīwardī, who composed several poems on this subject. In one of these he says:

Sons of Islām, behind you are battles in which heads rolled at your feet. 
This is an indication of the fact that even after the capture of and massacre in Jerusalem by the Franks, Muslim intellectuals continued to arouse the spirit of $j i \bar{h} \bar{a} d$ among the people. This is evident in the production of a number of genres, particularly jih $\bar{a} d$ (including poetry) and fad $\bar{a}^{\prime} i l$ (merits) literature, which attained special attention and attraction but have often been ignored by contemporary historians ${ }^{7}$ of the Crusades. This literature does provide us a vivid and wider picture of the Muslim interpretation of and response to the Crusades in the twelfth and thirteenth centuries. ${ }^{8}$

\section{Al-Sulami s Response to Crusades (Muslim Reformation and Jibäd Literature)}

As we have observed, Abū l-Hasan 'Alī ibn Ṭāhir al-Sulamī (1039/1040-1106) was probably the first Muslim intellectual and jurist who had a broader understanding and was aware of the goals of the Frankish incursion into Muslim lands; he was the first who rose to call Muslims to action, much as the Caliph did, to fight the enemy and to

Dare you slumber in the blessed shade of safety, where life is as soft as an orchard flower?

Must the foreigners feed on our ignominy, while you trail behind you the train of a pleasant life, like men whose world is at peace?

When the white swords' points are red with blood, and the iron of the brown lances is stained with gore!

This is war, and the man who shuns the whirlpool to save his life shall grind his teeth in penitence.

This is war, and the infidel's sword is naked in his hand, ready to be sheathed again in men's necks and skulls.

See Ibn al-Athīr, al-Kāmil fì l-tārīkh (ed. C. J. Tornberg; Beirut: Dār Ṣādir, 196567), X, 283-284; Francesco Gabrieli, The Arab Historians of the Crusades (translated from Italian into English by E. J. Costello; Abingdon \& New York: Routledge, 2010), 7.

7 Except Emmanuel Sivan's L'Islam et la croisa de: Idéologie et propaganda dans les reactions musulmanes aux croisades (Paris: Librairie d'Amérique et d'Orient, 1968) - a book widely quoted by crusade historians, which give a detailed study of fad̄' $i l$ (merits) literature.

8 Hadia Dajani-Shakeel, "A Reassessment of Some Medieval and Modern Perceptions of the Counter-Crusade," in Hadia Dajani-Shakeel and Ronald A. Messier (eds.), The Jihād and Its Times: Dedicated to Andrew Stefan Ehrenkreutz (Ann Arbor: University of Michigan, Center for Near Eastern and North African Studies, 1991), 49 (hereafter cited as "Perceptions of the Counter-Crusade"). 
defend the Muslims and their territories against the foreign onslaught of the Franks. Al-Sulamī, just a few years after the fall of Jerusalem to the Franks, took to the pulpit in the Masjid of Bayt Lihya in the ghüta area on the outskirts of Damascus to preach $j i h \bar{a} d$. In this way, over the course of the year 1105, he publicly dictated a treatise entitled Kitāb al-jihād (Book of jihād), which continued to be read in Damascus after his death in $1106 .{ }^{9}$ He was preaching and reviving the spirit of $j i h \bar{a} d$ in a myriad of new contexts among the followers of Islam as they were experiencing, for the first time, a new situation in which their lands were being attacked by an external, non-Muslim enemy; it was quite a different context from that of earlier Muslims who used to fight in the territory of non-Muslim enemies. Al-Sulamī in particular preached during a period of extreme urgency and deep crisis: The Crusades.

In his Kitāb al-jihād, al-Sulamī perceived the First Crusade within a divine framework, describing it as one of the greatest disasters that had befallen Islam and as an admonition from God to the Muslims that tested their dedication to Him and their obedience by following the true message of Islam, which included the jih $\bar{a} d$. Al-Sulami argues that the obligation of jih $\bar{a} d$ was smoothly and continuously established and practiced from the time of the Prophet Muhammad through to a certain (unnamed) caliph, he writes:

After (the death of) the Prophet [Muhammad] (God bless him) the four caliphs and all the Companions (of the Prophet) [enthusiastically practiced] it [jihād] during his caliphate, and those who were appointed as successors afterwards and ruled in their own time, one after another, followed them in that, the ruler carrying out an expedition himself every year, or sending someone out from his deputies on his behalf. It did not cease to be that way until the time in which one of the caliphs (unnamed in the text) left off (doing) it because of his weakness and negligence. Others followed him in this for the reason mentioned, or a similar one. His stopping this ... made it necessary that God dispersed their unity, split up their togetherness,

9 For a brief biography of al-Sulamī, see David Thomas and Alex Mallet (eds.), Christian-Muslim Relations: A Bibliographical History, 1050-1200 (Leiden: Brill, 2011), III, 307-308; also more details about his book (Kitāb al-jihād) and preaching the $j i \bar{a} \bar{a} d$ can be found in Suleiman A. Mourad and James E. Lindsay (eds.), The Intensification and Reorientation of Sunni Jihad Ideology in the Crusader Period 3 (Leiden: Brill, 2013), 33-36. 
threw enmity and hatred between them, and tempted their enemies to snatch their country from their grasp and (so) cure their hearts of them. ${ }^{10}$

Al-Sulamì believed that once the Muslims were ready to abide by God's commands, He would help them against the enemy. As such, the attack of Franks into Islamic territory was but a punishment of God for not executing and upholding the jihād. How should the Muslims now confront the ruthless Crusaders (Franks) who had already taken Jerusalem and other major portions of the Levant? According to al-Sulamī, writing in such a distinct situation would affect how Muslims would construe the obligation to struggle for justice. Al-Sulamī, citing the famous legalist al-Shāfici (d. 206/820), notes that the imām (the leader of the Muslim community, or the Caliph) was responsible for raising an army to undertake expeditions into enemy territory at least once a year. ${ }^{11}$ The minimum responsibility placed on an imām was to lead the army either personally or through a deputy. If he did not send enough troops to fight, then it became the duty of those "in the rear" to go out and fulfill God's command; in the case of urgency or necessity, the obligation of fighting ( ghazwa) was incumbent (fard ' $a y n)$ upon all the members of the community. ${ }^{12}$ The current situation, al-Sulami believed, was one such instance because enemy armies were making inroads into Muslim territory. Dajani-Shakeel, however, observes, "the twelfth-century interpretation of the doctrine of jiha $\bar{d}$ las the treatise of al-Sulamī] departed, to some extent, from the classical interpretation of the doctrine, due to circumstantial differences as well as to the nature of the enemy." ${ }^{13}$ Al-Sulami further cites the views of the twelfth century's greatest theologian and philosopher, Abū Ḥāmid Muḥammad al-Ghazālī (d. 505/1111), on the jihāad. According to al-Ghazāli, $j i h \bar{a} d$ was a duty of every free, able Muslim, and its aim

10 Niall Christie, The Book of the Jihad of 'Ali ibn Tabir al-Sulami (d. 1106): Text, Translation and Commentary (Farnham, England: Ashgate Publishing, 2015), 206 (hereafter referred as Book of the Jihad).

11 The aim of such yearly undertaking was to defend Muslim territory and gather intelligence information about any military movements of the enemy.

12 Christie, Book of the Jihad, 207; Dajani-Shakeel, "Perceptions of the CounterCrusade," 52-53; John Kelsay, Arguing the Just War in Islam (Cambridge, MA: Harvard University Press, 2007), 116.

13 Dajani-Shakeel, "Perceptions of the Counter-Crusade," 52-53. 
was to try "to exalt the word of God (who is praised), to demonstrate his religion, to suppress by it his enemies the polytheists, to achieve the reward which God (who is praised) and His Prophet promised him from (fighting) the jihād in His cause." He makes clear, according to Christie, that the jiba $\bar{a}$, however, is an obligation of sufficiency; as al-Ghazālī puts it:

If the group which was facing the enemy had enough people in it, then it would be possible for them (the group) to fight hard against them (the enemy) (by) themselves, and to remove their evil separately from others. Yet if the group was weak, and was not able to be sufficient (to face) the enemy and to defeat their evil, then the obligation (to help) is imposed on the people of the nearby countries. ${ }^{14}$

Al-Ghazālī was certain to mention, Christie further observes, that the $j i h \bar{a} d$ was defensive in nature in terms of the Muslim response to the First Crusade. Taking al-Shām (Syria) as an example, al-Ghazāli says:

If the enemy attacks one of its [Syrian Muslim] cities, and there are not enough people in it to fight and defeat them, it is obligatory on all the cities belonging to Syria to send people to it to fight until there are sufficient (people). At that time the obligation falls from the others because the lands of Syria are like one town. If those who are able from them come to fight the enemy and not enough undertake (the fighting of) them, coming to fight them and joining battle with them is also obligatory for those who are near Syria, until there are enough. At that time the obligation also falls from the others. If the enemy surrounds one town, the obligation of the jihād likewise becomes incumbent on all who are there, whatever befalls its location. ${ }^{15}$

Dajani-Shakeel argues that al-Sulamī, worried by the advance of the early Crusaders in Syria, was more moving than al-Ghazālī in defining the jihād because he was trying to inspire enthusiasm among the Damascenes. He was preaching to them amidst the danger of their city's fall to the Crusaders and was trying to rouse them to action. Therefore, al-Sulami notes that all the instructions mentioned by the early jurists' in regard to the jih $\bar{a} d$ and its rules and regulations actually aimed at:

\footnotetext{
14 Christie, Book of the Jihad, 208.

15 Ibid.
} 
Carrying it $(j i h \bar{a} d)$ into enemy territory, be they near or far. However, if the enemy raids Muslim lands and attacks their country, such as these forsaken (the Crusaders) did, then we are obliged to go to fight them and seek them out in the country that they usurped from the Muslims, which is a war of resistance, aimed at defending ourselves, children, and property, and at safeguarding lands that are still under Muslim control. ${ }^{16}$

With a different interpretation from the earlier juristic views, he further adds, "Had it not been for the purpose of uprooting them (the Crusaders), and recovering the territories, then, marching against them, in such a situation, could neither be labeled as jihād nor as ghazwa (expedition)." ${ }^{17}$ For this reason, he again reiterates that jihäd is obligatory "on each person who is able, with no impediment of blindness, serious illness or excessive age, which makes it impossible to move, to prevent him from it $[j i h \bar{a} d] .{ }^{.18}$

Al-Sulamī's call for $j i h \bar{a} d$ as a defensive matter was not only trying to boost and arouse morale among the ordinary people but also trying to mobilize the rulers of the Muslims (the Sultan or the Caliph in Baghdad) because they were more responsible for upholding and continuing the $j i \bar{a} \bar{a} d$. He called upon the sultan to act immediately in what God had made "a duty to him of guarding the religion [Islam], guiding the Muslims and defense of himself, his army and them (the Muslims)." ${ }^{19}$ Admonishing him (the Sultan), he says: "if the authorities do not pay any heed to the duty, then they should remember the Prophet Muhammad's saying, 'Whoever looks after a group of subjects, and does not give them good advice [nașīha], God has forbidden him Paradise'." Further explaining the term advice (nașị̧a), al-Sulamī says that it also means, "watching over his subjects, protecting them and driving the harmful enemies from them." Supporting and extending his argument with additional $\operatorname{sharì}^{\prime} a$ references, he quotes another hadith, which says, "All of you are guardians, and all of you are responsible for His subjects." ${ }^{20}$

\footnotetext{
16 Ibid, 233; see also Dajani-Shakeel, "Perceptions of the Counter-Crusade," 53-54.

17 Christie, Book of the Jihad, 233.

18 Ibid., 232; see also Dajani-Shakeel, "Perceptions of the Counter-Crusade," 53-54; Kelsay, Arguing the Just War in Islam, 117.

19 Christie, Book of the Jihad, 233.

20 Ibid., 234; Dajani-Shakeel, "Perceptions of the Counter-Crusade," 54; See al-Imām
} 
Al-Sulami declared that the key to $j i h \bar{a} d$, which is a religious duty,

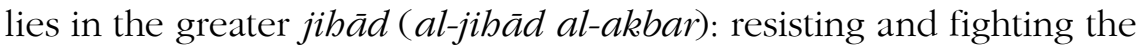
evil impulses of the soul and following the ethical code of Islam. This, considered by many Muslims as the real $j i h \bar{a} d$, is a spiritual $j i h \bar{a} d$. He called upon the Muslim Caliph and all other rulers of al-Shàm, alJazira, and Egypt to shun their ideological differences and to unite at this critical time (i.e., the Crusades). In addition, al-Sulamī reiterated, "in severity, hatreds go", for he recounted that even early Arab adversaries used to unite in times of crisis or against a universal enemy, and when the crisis ended, they would either remain as allies or divide again as they had been before. Thus, he preached that Muslims should follow the example of their predecessors and foster amiable and friendly relationships with each other in a critical situation such as the Crusades. ${ }^{21}$

It is important to remember that al-Sulami was preaching at the time of an almost complete power vacuum in the Muslim world. As Dajani-Shakeel wrote, "there were leaders who lacked both the moral qualities and the will to fight against the invaders."22 Therefore, alSulami tried to remedy this vacuum through two important developments: first, the mobilization of fighting scholars and intellectuals; and second, the rise to power of ghāzí-caliphs, or rather, in these circumstances, ghāzì-sultans who would be stirred by the pain of the Muslim community. His treatise on $j i h \bar{a} d$, surprisingly, traced the broad outline of what actually happened subsequently. This helped to develop the long process of what later came to be known as the Counter-Crusade (a misnomer). ${ }^{23}$

As for the first remedy, al-Sulamī did help to mobilize religious scholars and he himself emerged from the political chaos just after the

Abū 'Abd Allāh Muḥammad ibn Ismācīl al-Bukhārī, Șaḥ̂̄h al-Bukhārī (translated into English by. Muḥammad Muḥsin Khān; Riyadh: Dār al-Salām, 1997), "alNikāḥ," vol. 7, hadīth 5188.

21 Christie, Book of the Jihad, 234; Dajani-Shakeel, "Perceptions of the CounterCrusade," 54.

22 Dajani-Shakeel, "Perceptions of the Counter-Crusade," 55.

23 Michael Bonner, Jihäd in Islamic History: Doctrines and Practices (Princeton \& Oxford: Princeton University Press, 2006), 139-140 (hereafter cited as Jihād in Islamic History). 
First Crusade actually taking up arms against the Crusaders. ${ }^{24}$ Counting the role of these fighting scholars, Michael Bonner in his Jihäd in Islamic History: Doctrines and Practice, adds, "From a strictly military point of view, their contribution may have been negligible, but from a broader political point of view, it mattered considerably. In particular, legal and religious scholars had a visible role in the first major Muslim victory over the Crusaders at Balat in 1119." ${ }^{25}$ During the second mobilization, ghāzī-sultans took longer to come forward and to reconstitute their own forces, but as we know, this issue eventually dominated the Muslim political scene. The leadership vacuum that had been created was later filled primarily by three charismatic leaders of jibād: 'Imād al-Dīn Zangī (d. 541/1146), his son Nūr al-Dīn Maḥmūd Zangī (d. 570/1174) and Ṣalāḥ al-Dīn (d. 589/1193). They each contributed to the task (the military response, as will be explored and explained shortly) that ultimately liberated the whole Levant from the Crusaders. ${ }^{26}$ They revived the spirit of jih $\bar{a} d$ and unity among the Muslims.

In defense of the Islamic heartlands and to continue to inspire among Muslims the spirit of fulfillment of God's duty, new works on the $j i h \bar{a} d$, such as al-Sulamì's, were recited on public occasions, together with older ones, such as the Book of jibād (a work of hadith) by the Iranian 'Abd Allāh ibn al-Mubārak (d. 181/797). ${ }^{27}$ However, this was only one aspect of the works of $j i h \bar{a} d$ - those devoted to the theoretical aspects of its doctrine, says Atiya. The other aspect, he adds, is even more extensively examined by writers. He remarks:

In fact, a whole literature arose to deal with the practical issues of the Eastern art of war, more particularly in the later Middle Ages. Treatises on equestrian art and chivalry, on armor and the proper manipulation of each weapon, the technique of fighting, tactics, and the order of battle were compiled by warriors and generals of proven experience and accurate knowledge of military science. The vast output of

\footnotetext{
24 See Hillenbrand, Crusades: Islamic Perspective, 26.

25 Ibid.

26 Dajani-Shakeel, "Perceptions of the Counter-Crusade," 55; see also Bonner, Jihäd in Islamic History, 140.

27 Bonner, Jihād in Islamic History, 100, 140.
} 
Muslim writers in this important field more than justifies a monumental study on the history of the Eastern art of war... ${ }^{28}$

Equally important was the emergence of a particular genre of literature - fad $\bar{a}^{\prime} i l$ (merits or eulogies or in-praise) literature; new books on particular cities, including Mecca, Medina, Damascus, and Jerusalem, were passionately written by Muslim scholars and preachers symbolizing the importance and status of these cities in Islam. Above all, Jerusalem received particular attention with a large number of books and treatises flourishing during the Crusade period. Jerusalem is the third holiest site in Islam, after Mecca and Medina in Saudi Arabia, and though it enjoyed an important place in Islam through its history, it attained symbolic importance for the Muslim campaign partly in response to the Crusaders' searing passion for that city, which they invaded and captured during the first Crusades in 1099. The fadā'il al-Quds (eulogies of Jerusalem) literature also characterizes the intellectual response to the Crusades and needs to be explored.

\section{Fad̄ā'il al-Quds Literature}

The centrality of Jerusalem (in Arabic "al-Quds," or "Bayt almuqaddas," or "Bayt al- maqdis" [House of Holiness]) in Islam played an influential role in the Muslim response to Crusades because the various elements involved in the process of Jerusalem's elevation in sanctity during the crusades were not new. These traditions (of Jerusalem's holiness) developed during the early Middle Ages and appeared in the extant sacred and primary Islamic sources - the Qur'ān and the Prophetic traditions; an analysis of the rich Arabic and Islamic literature on Jerusalem reveals an increasing general Islamic awareness of al-Aqșâ's ${ }^{29}$ and al-Quds sacred status. Therefore, it

28 Azīz Suryal Atiya, Crusade, Commerce, and Culture (Bloomington: Indiana University Press, 1962), 136.

29 Al-Masjid al-Aqșā or "the farthest place of prayer," also commonly identified as bayt al-muqaddas or maqdis, is unanimously regarded as the third holiest site in Islam, and is located on the eastern edge of the Old City of Jerusalem (al-Quds). More precisely al-Aqșā is a compound that houses the complex of buildings and monuments in what is called in Islam al-haram al-sharif (The Noble Sanctuary).

As for al-Aqșā Masjid, al-ḥarām refers to the whole area inside the walls, including the main building of the Masjid, the marwāni mușallā (mușallā is a small prayer place, smaller than, or a part of, a masjid), the Dome of the Rock 
seems appropriate to examine the status of Jerusalem as envisioned in Islamic traditions before we proceed and discuss the fad $\bar{a}^{\prime} i l$ literature.

In the Qur'ān, the land of Jerusalem/Palestine is mentioned as "alard al-muqaddasa" ${ }^{30}$ or "the sanctified land" and all of Syria is generally believed to be the blessed land. ${ }^{31}$ Jerusalem's importance in general and al-Masjid al-aqșā's (the Farthest Masjid) in particular to the Muslims is obvious from the fact that the name of the Masjid itself is indicated in the seventeenth sūra (chapter) of the Qur'ān. According to the Qur'ānic reference, the Prophet Muhammad was taken on a miraculous Night Journey from Mecca to the place (in Jerusalem) called al-Masjid al-Aqșā; the Qur’ān says: "Glory be to him Who carried His Servant (Muhammad by night, from the sacred place of prayer (al-Masjid al-harām) to the farthest place of prayer (al-Masjid al-Aqșā), The precincts of which We have blessed, that We might show him some of Our signs. He is the All-Hearing, the AllSeeing." ${ }^{\prime 2}$ The Prophetic tradition further explains and continues al$i s r \bar{a}$ ' "the Night Journey" verse by reporting that it is from this Masjid that the Prophet Muhammad, who was riding on a heavenly creature (a white animal) called al-Burāq to the Farthest Masjid, ascended to heaven $\left(a l-m i{ }^{(} r \bar{a} j\right) .{ }^{33}$ Since then, Muslims have called the city "the gate to the heavens." In this journey, it is reported that the Prophet Muhammad led all the prophets in a nightly congregation prayer in Bayt al maqdis. ${ }^{34}$ Moreover, a number of prophetic traditions further

(Qubbat al-șakra) and the grounds that connect all of them inside the walls. The whole area of the masjid is 14 hectares, about 15 percent of the area of the Old City (the Old City's area is 1 square kilometer). The main building of al-Aqșā Masjid rests on the southern part of al-Haram al-sharif and its interior is 75 meters long and 55 meters wide. It has no minaret but a dome in the center of the ceiling covered by silver.

30 Q 5:21.

31 Q 21:71; 21:81.

32 Q 17:1.

33 See al-Bukhārī, "Bad' al-khalq," vol. 4, hadīth 3207; Abū 1-Husayn Muslim ibn alHajjāj al-Qushayrī, Șaḥ̄h Muslim (translated into English by Naṣīr al-Dīn alKhațāāb (Riyadh: Dār al-Salām, 2007), "Īmān," vol. 1, hadīth. 162.

34 Ibn Kathīr, Tafsīr Ibn Kathīr-Abridged Volume 5, Surah Hud to Surat Al-Isra', Verse 38 ( ${ }^{\text {rd }}$ edn., Riyadh, Houston, New York \& Lahore: Darussalam Publishers, 2003), 556. 
raise the status of al-Aqșā for the Muslims. Because it was the $\bar{u} l \bar{a} l$ qiblatayn (first direction of prayer), the Messenger of Allah prayed in the direction of al-Masjid al-aqșā for sixteen or seventeen months (a Qur'ānic injunction later commanded the Prophet to direct the prayer toward Mecca)..$^{35}$ According to another prophetic tradition, Muslims are encouraged to do journey to al-Aqșā Masjid ${ }^{36}$ because a single prayer at al-Aqșā is regarded as the equivalent of 500 prayers at other masjids and inferior in value only to prayer at al-Masjid al-harām in Mecca and at the Prophet's Masjid in Medina. ${ }^{37}$ It is also reported that when the Prophet Muhammad was asked about the first mosque built on earth for mankind he replied that it was al-Masjid al-harām in Mecca; when he was subsequently asked about the second, he is reported to have replied, "al-Masjid al-aqșā with forty years between them." 38

Given that, there was an extensive effort to explain and exalt Jerusalem's status through a genre of literature termed fad $\bar{a}^{\prime} i l$ alQuds or fada $\bar{a}^{\prime} i l$ Bayt al-maqdis, an effort that would be revived after the Frankish Christians had taken the Jerusalem.

One of the most influential texts of this type was the Fad $\bar{a}^{\prime} i l$ alBayt al-Muqaddas ${ }^{39}$ (Merits of Jerusalem) of al-Wāsițī (fl. ca. 410/1019), the preacher (al-khatīb). It is a compilation of over 500 prophetic hadith illustrating the merits of Jerusalem (al-Quds). His work was copied, quoted from, and summarized throughout the twelfth and thirteenth centuries. Another important work of this type is the Fad̄a $\bar{a}^{\prime}$ Bayt al-maqdis wa-l-Shām wa-l-Khalìl of Ibn al-Murajjā al-Maqdisī (fl. ca. 430/1130), which is the largest and most important of the "In-Praise-of-Jerusalem" literature. It is a collection of 594

See al-Bukhārī, "Ṣalāt, "vol. 1, ḥadīth 399; Muslim, "Masājid wa-mawāḍic al-ṣalāt" vol. 2, hadith 525 .

36 See al-Bukhārī, "Faḍl al-ṣalāt fī masjid Makka wa-l-Madīna," vol. 2, hadīth 1189; al-Imām al-Ḥāiż Abū 'Īsā Muḥammad ibn 'Īsā al-Tirmidhī, Jāmic Tirmidhō (translated into English by Abū Khalīl; Riyadh: Dār al-Salām, 2007), "Ṣalāt," vol. 1, hadìth 326.

37 Abū Bakr Aḥmad ibn al-Husayn ibn 'Alī al-Bayhaqī, Shu'ab al-ìmān (Riyadh: Maktabat al-Rushd, 2003), "Faḍl al-ḥajj wa l-cumra," vol. 6, ḥadìth 3845.

38 See al-Bukhārī, "Ahāēìth al-anbiyāè," vol. 4, ḥadīth 3366.

39 Abū Bakr Muḥammad ibn Aḥmad al-Wāsițî, Faụā’il al-Bayt al-muqaddas (ed. Isaac Hasson; Jerusalem: Dār Māghnis, 1979). 
traditions which, among other things, praises Jerusalem, Syria, and Hebron. The fadā'il books by Abū Bakr al-Wāṣiți and Ibn al-Maqdisī pre-dated the First Crusade, but this type of literature, engendered principally in response to the Crusades, drew the attention of Muslims to Jerusalem and to engage in jiha $\bar{a} d$ (holy war) to free it and other lands from the Crusaders. The fad $\bar{a}^{\prime} i l$ literature is important to understand the Islamic meaning of Jerusalem and al-Masjid al-aqșā..$^{40}$ 'Abd al-Salām al-Rumaylī (d. 492/1099) was a pupil of al-Maqdisī and was also reported to have written a treatise on Jerusalem in which he collected fad $\bar{a}^{\prime} i l$ traditions. Al-Rumaylī was killed by the Crusaders at the time of the invasion in the First Crusade. We are told that he was stoned while in captivity near Beirut on 12 Shawwāl 492 AH or 1 December 1099 AD. ${ }^{41}$

In the 1160 s C.E., this genre of literature reappeared after a short period of silence. Ibn 'Asākir al-Dimashqī al-Shāfi'̄i al-Ash'arī (499571/1106-1176) - an imām (authority) of hadīth, a great historian, and a prolific writer who authored over a hundred books and epistles in his time in Damascus and was the friend of Nūr al-Dīn - also produced a treatise on the merits of Mecca, Medina, and Jerusalem

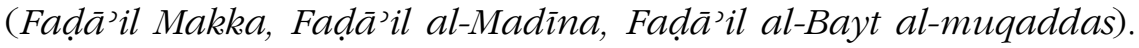
His Tārīkh Madinat Dimashq (History of Damascus City), ${ }^{42}$ published in eighty volumes, extensively addressed the history, geography, and society of Damascus. He was also said to have written a treatise on jiha $\bar{a}{ }^{43}$ We also have another work, Fad̄' 'il al-Quds al-sharîf by Ibn al-Jawzī (d. 597/1201); and it also contains traditions about Jerusalem and the "holy land" (allard allmuqaddas), its foundational șakbra

40 Yitzhak Reiter and Marwān Abū Khalaf, "Jerusalem's Religious Significance: Jerusalem in the Faiths of Judaism, Christianity, and Islam," Palestine-Israel Journal 8/1 (2001), available at http://www.pij.org/details.php?id=169; see also Amikam Elad, Medieval Jerusalem and Islamic Worship: Holy Places, Ceremonies, Pilgrimage ( $2^{\text {nd }}$ edn., Leiden: Brill, 1999), 14 (hereafter cited as Medieval Jerusalem); Moshe Gil, A History of Palestine: 634-1099 (Cambridge \& New York: Cambridge University Press, 1992), 98.

41 On this, see Gil, A History of Palestine, 422-424; see also Hillenbrand, Crusades: Islamic Perspective, 66, 163.

42 Abū l-Qāsim 'Alī ibn al-Ḥasan Ibn 'Asākir, Tarīkh Madīnat Dimashq (ed. 'Umar ibn Gharāma al-'Amrawī and 'Alī Shīrīi Beirut: Dār al-Fikr, 1995-2001).

43 Hillenbrand, Crusades: Islamic Perspective, 164. 
("rock") and, among other things, its association with the Prophet Muhammad during his $m i$ 'rōjj.

The production of fad $\bar{a}^{\prime} i l$ literature obviously could have enhanced the desire on the part of Muslims to reconquer Jerusalem. Equally important is that Ibn 'Asākir's work glorifying Jerusalem was read publicly to large audiences in Damascus from the AD 1160s, onwards. Consequently, such mass gatherings and preaching could have reawakened and strengthened the sanctity of Jerusalem in the popular consciousness and built up the expectation that the Holy city would be recaptured. ${ }^{44}$ Although the Crusades added a new dimension to the significance of Jerusalem, it was the great sanctity and status that the city enjoyed long before the Crusades, as we mentioned, that made it the symbol of the jihād against the Franks. ${ }^{45}$ Aziz S. Atiya has aptly remarked, "the Muslim was bound by his religion not only to visit those places but also to preserve them within the pale of the Islamic Empire and defend them against the Crusader." ${ }^{46}$ One should, however, note that all of the Jerusalem "Praise-in-Literature" did not aspire to make it a pilgrimage destination in rivalry with Mecca. Rather all the particular genres $j i h \bar{a} d$, including jiha a d poetry, fad $\bar{a}^{\prime} i l$ al-Quds-intended to revive the spirit of $j i h \bar{a} d$ among the Muslims who were confounded by internal discord; indeed, it helped to foster Muslim unity, a prerequisite to fight their common enemy; however, it took a longtime to organize a

44

45 Western historians often contend, out of their stereotypical, inimical and biased approach toward Islamic texts, that after the fall of Jerusalem to the Franks, Muslim jurists and religious scholars engendered and orchestrated on their own, with no reference to Islam, the status of Jerusalem, which they then exploited to the fullest possible extent in a propaganda campaign to garner support for their personal political ambitions, if not for the real jiha $\bar{a} d$. On the contrary, as we have pointed out, Jerusalem enjoys a special place in Islam and will continue to do so; it was not just for mere political reasons that Muslim rulers strongly yearned to recapture of Jerusalem, and they did so out of their religious conviction. Equally important is that they were fighting the real enemy, the Crusaders. Western scholars' bewilderment is that they often see the Muslim world through a Western perception even after they have great expertise in the Arabic language; for more details, see for example, Elad, Medieval Jerusalem, especially 1-50; Hillenbrand, Crusades: Islamic Perspective, 141-167.

46 Atiya, Crusade, Commerce, and Culture, 133. 
strong unified resistance until Nūr al-Dīn came to the scene. In fact, his father 'Imād al-Dīn took the initiative in the truest sense, which later his son astutely imitated, followed by the great Șalāh al-Dīn of Ayyūbid dynasty who actually did help Muslim to realize the success.

\section{Military Response to the Crusades}

The Muslim military response to the Crusades, as we have already mentioned, was not unified or organized at first. It took time for Muslim intellectuals and rulers to convert the theory of jih $\bar{a} d$ into practice following the continuous calls for jihäd against the Franks, which reverberated everywhere.

Nevertheless, the first physical encounter that took place between the Seljuk sultan of Rūm, Qilij Arslān I (r. 1092-1107) and the Crusaders occurred when the first wave of the First Crusade (the People's or peasants' Crusade) tried to intrude into the Seljuk territory in the autumn of 1096. However, the people's Crusade totally failed to advance and a majority of them were killed. However, after this initial Muslim success, Crusaders managed to sweep across Asia Minor until they succeeded in establishing the four major CrusaderStates in the Levant, including Jerusalem. Muslims were struck with shock and outrage, and poets and preachers reiterated calls to both the local rulers in the Levant and the Great Seljuk sultan in the east for jiba $\bar{a} d$ and aid in defending the Muslim lands against the Frankish invasion. Thus, after the fall of Tripoli in 1109 to the Franks, the Great Seljuk sultan Muhammad (r. 1105-18) moved to act and launched a number of expeditions against the Franks, but again internal discord became a hurdle. Like the Fātimids of Egypt, the local rulers of the Levant had made alliances with the Franks, and thus the sultan had to abandon the expedition without any major success. ${ }^{47}$

Despite the failures, the spirit of $j i h \bar{a} d$ remained alive; there was a strong local reaction amongst religious scholars, but it had yet to be harnessed into a full-scale military campaign because it was not backed up by the rulers or political authorities in a concerted fashion. It is believed that the first major turning point in Muslim success and the subsequent reawakening of an organized jih $\bar{a} d$ came with the fall

47 Niall Christie, Muslims and Crusades: Christianity's Wars in the Middle East 1095-1382 From the Islamic Sources (New York, NY: Routledge, 2014), 19-20 (hereafter cited as Muslims and Crusades). 
of Edessa in 539/1144. However, the wave was already beginning to turn in the preceding decades; slowly and gradually, the isolated jih̄ād campaigns had already begun. ${ }^{48}$

The first tentative turning-point for the Muslims was in the year 1119 when the Turkmen ruler of the Mardin, Ilghāzì (r. 1108-1122), was asked by the citizens of Aleppo, who had sought military help from Baghdad, to take control of their city and defend it against Roger of Antioch. Ilghāzī took over and tried to be an ideal leader of jihād. He went on to win the first victory of the Muslim response (or the Counter-Crusade as Western scholars call it) at the battle at Balat; he defeated and killed Roger of Salerno, the regent of Antioch (r. 11131119). The Frankish loss and the destruction were so severe that the battle came to be called the Field of Blood. It is reported that a famous Muslim religious figure, al-Qāẹi Abū l-Fạ̣l ibn al-Khashshāb of Aleppo, was closely involved in running the affairs of Aleppo and took part in the battle of Balat himself. Ilghāzī, however, could not capitalize on his success because he died in 1122, leaving the Aleppans disappointed, if not frightened. ${ }^{49}$

Ilghāzī's nephew, Nūr al-Dawla Balak, also became engaged with the jih $\bar{a} d$ against the Franks. It is said that he displayed tremendous vigor in a number of encounters against them, and he is extolled as a Muslim champion in the wars against the Crusaders; but he was killed outside Manbij in 518/1124 and was buried in Aleppo..$^{50}$ The political vacuum created was immediately filled by the Zangi dynasty. It was under the leadership of 'Imād al-Dīn Zangī, who became the governor (atābeg) of Mosul in 1127 and Aleppo in 1128, that the first organized Islamic military response began to emerge, comprising both religious and political figures in their first key victory against the Franks with the fall of Edessa $(a l-R u h \bar{a})$ in 1144 . With this victory, the good fortune of the Muslim world in its jihäd campaign against the Franks boosted the spirit of $j i h \bar{a} d$ and raised their morale; they now began to look toward the conquest of Jerusalem, but it was never accomplished in his lifetime.

\footnotetext{
48 Hillenbrand, Crusades: Islamic Perspective, 108.

49 Ibid., 109; see also, Jonathan Riley-Smith (ed.), The Oxford History of the Crusades (New York: Oxford University Press, 1999), 225.

50 Hillenbrand, Crusades: Islamic Perspective, 110.
} 
It was in this atmosphere of turmoil, intimidation, and extreme humiliation of the Muslims that fortune favored the community of monotheists (al-hanifiyya) and helped them out of their precarious condition by supporting the believers in their struggle and bringing forth 'Imād al-Dīn Zangī as their leader. Ibn al-Athīr eulogized the Zangi for this great achievement (the capture of Edessa) and for reviving Islamic values ( $j i h \bar{a} d$ and unity); he expresses the achievements of 'Imād al-Dīn Zangī in a panegyrical passage:

When Almighty God saw the princes of the Islamic lands and the commanders of the Hanafite creed and how unable they were to support the [true] religion and their inability to defend those who believe in the One God and He saw their subjugation by their enemy and the severity of their despotism ... He then wished to set over the Franks someone who could requite the evil of their deeds and to send to the devils of the crosses stones from Him to destroy and annihilate them [the crosses]. He looked at the roster of valiants among His helpers and of those possessed of judgment, support and sagacity amongst His friends and He did not see in it (the roster) anyone more capable of that command, more solid as regards inclination, stronger of purpose and more penetrating than the lord, the martyr (al-shabid) 'Imād al-Dīn [Zangī] ${ }^{51}$

'Imād al-Dīn Zangī became famous in the Muslim world for his brilliant leadership qualities and his military and political skills. He was even more remembered as a true mujäbid (the one who carries out $j i h \bar{a} d$ ), "The adornment of Islam, the king helped by God, the helper of the believers" against the Franks, is thus portrayed as a real hero of Islam. In fact, it was only after the recapture of Edessa that Muslims' call for jibād began to receive momentum and that he reunited the Northern Syria. Two of the famous poets of the time, Ibn al-Qaysarānī and Ibn Munīr, as Hillenbrand wrote, "eloquently urged Zangi ... to make the reconquest of the entire Syrian coastline (the säbill) the principal aim of jihad." ${ }^{2}$ Zangi is also reported to have patronized and sponsored the foundation of many religious seminaries - madrasas and khanqābs - as "part of a broader movement of moral rearmament, in which both rulers and the

51 Ibn al-Athīr, al-Tārīkh al-bāhir fì l-Dawla al-Atābakiyya bi-l-Mawșil (ed. 'Abd alQādir Aḥmad Ṭulaymāt; Cairo: Dār al-Kutub al-Hadìtha, 1963), 33-34 (hereafter cited as al-Bāhir); see also Gabrieli, The Arab Historians of the Crusades, 25.

52 Hillenbrand, Crusades: Islamic Perspective, 114. 
religious élite devoted themselves to stamping out corruption and heterodoxy in the Muslim community, as part of a grand jih $\bar{a} d$ which had much wider aims than merely the removal of the Franks from the coastline of Palestine." ${ }^{53}$ However, before he could move to gain more territories, particularly Damascus, from Frankish possession, 'Imād al-Dīn Zangì died in 1146, just two years after his victory over Edessa.

Nūr al-Dīn Zangī (r. 1146-1174) succeeded his father 'Imād al-Dīn in Aleppo, and he brilliantly imitated and continued his father's jihād spirit by fighting numerous battles against the Franks to move inexorably towards the acquisition of Damascus and later the reunification of Syria and Egypt under the banner of the Sunni Caliphate based in Baghdad. He is regarded in the Muslim sources as the real architect of the Muslim response to the Crusades.

In 1147, Nūr al-Dīn helped to relieve the siege ${ }^{54}$ of Damascus ${ }^{55}$ by the Second Crusade, which was launched in response to the fall of Edessa. Realizing his father's dream in 1154, Nūr al-Dīn made a successful entry into Damascus with the help of an "eager pro-jihād faction within the walls of Damascus;" thus, by that year, he had almost united Syria. In the middle of the twelfth century, Muslim sentiments toward Jerusalem and the importance of the jiba $\bar{a} d$ were increasingly intense, and this popular force had helped surrender Damascus to Nūr al-Dīn because many held him in high esteem and considered him to be the real leader who would reclaim Jerusalem for Muslims. ${ }^{56}$ His perseverance in fighting for the recovery of

53 Riley-Smith, The Oxford History of the Crusades, 226.

54 All the Muslim historians recorded with great pains the martyrdom of two most influential scholars, the Malikite faqīh Yūsuf al-Findalāwī (543/1148) and the devout Sufi scholar 'Abd al-Raḥmān al-Ḥalhūlī (543/1148), who were martyred while defending the city against the Crusaders. Both aged men, they were riding horses in the battlefield and fighting the enemy. This explicitly made clear the unified alliance between religious circles and the political leadership against the Crusaders.

55 At that time, Damascus was ruled by Mujīr al-Dīn Abaq ibn Muhammad ibn Būrī ibn Țughtikin, but he wielded no effective power; the real commander was $\mathrm{Mu}^{\top}{ }^{\mathrm{i}} \mathrm{n}$ al-Dīn Unur, one of his grandfather Țughtikin's Mamlūks. It was he who had put Mujīr al-Dīn on the throne; for more on this, see Gabrieli, The Arab Historians of the Crusades, 36.

56 Ira M. Lapidus, A History of Islamic Societies ( $2^{\text {nd }}$ edn., Cambridge \& New York: 
Jerusalem was perhaps best demonstrated when Nūr al-Dīn, while at Aleppo, commissioned a special minbar, or pulpit, intended to be placed in the Aqșā Masjid in Jerusalem in the expectation of that city's imminent re-conquest by his armies. ${ }^{57}$ The pulpit was eventually installed by Nur al-Dīn's successor, Șalāḥ al-Dīn, in the Aqșā Masjid in 583/1187, where it remained until 1969 when it was destroyed by Christian fanatics. ${ }^{58}$ Hence, it was during Nūr al-Dīn's time that Jerusalem became the focus of the ideological campaign of the Counter-Crusade, and it was from Damascus that this ideological campaign originated.

The Latin kingdom of Jerusalem as the dominant power in alShām region helped rapprochement among the different Muslim rulers, all of whom were facing a common threat - the Crusaders. However, Muslim rulers often sought help against their rivals by entering into shifting alliances with both the Franks and other Muslims as the circumstances changed. Therefore, before Nūr al-Dīn could embark on his biggest mission - the liberation of Jerusalem from the Crusaders - the political upheavals in the Egypt changed the whole situation. One of the Egyptian ministers (wazìns), al-Ṣālị IbnRuzzīq (d. 556/1160) approached Nūr al-Dīn Zangī - who, according to Dajani-Shakeel, had become the undisputed leader of the jihād in Damascus - suggesting that both leaders coordinate their military attacks against the Latin Kingdom of Jerusalem from Egypt and Syria. However, shortly after the wazier's assassination in 1161, there was a power struggle resulting in the weakening of Fātimid rule. Meanwhile, a new Crusader ruler, Amalric, had ascended the throne in 1163 in the Latin Kingdom of Jerusalem and, upon learning of the power vacuum in Egypt, made an alliance with Shāwar, one of the rivals of the installed Fāṭimid ruler, Dịgām. ${ }^{59}$ Shāwar was maneuvering to seize the control of Egypt. Egypt was considered strategically important by both the contending factions - Muslims and Franks - and also had great wealth and boundless resources; thus,

Cambridge University Press, 2002), 290.

57 Riley-Smith, The Oxford History of the Crusades, 227; on this for more details, see Hillenbrand, Crusades: Islamic Perspective, 151-161.

58 See Dajani-Shakeel, "Perceptions of the Counter-Crusade," 57; Hillenbrand, Crusades: Islamic Perspective.

59 Cf., Ibn al-Athīr describes an agreement between Shāwar and the Franks in 562/1167, see, Ibn al-Athīr, al-Bāhir, 134. 
unsurprisingly, both began to look at Egypt as a more urgent priority, as Riley-Smith has observed:

The Fātimid caliphs of Egypt had become the impotent pawns of feuding military viziers and ethnically divided regiments. There were some in Egypt in the 1150s and 1160s who favoured coming to terms with the kingdom of Jerusalem in order to secure its assistance in propping up the Fāṭimid regime, while others rather looked to Nūr alDīn in Damascus for help in repelling the infidel. ${ }^{60}$

Shāwar sought help from the Franks, and this eventually prompted Nūr al-Dīn, who was fulfilling his family and religious ambition of the reunification of the Islamic territories and the mobilization of the Islamic forces, to send an army under the Kurdish commander Asad al-Dīn Shīrkūh and Shīrkūh's nephew, Șalāh al-Dīn Ayyūbī, in 1169 to help the weakening Fātimid empire against the Franks and their Muslim allies. ${ }^{61}$ This war among the three contenders, Franks, Muslims and Fāțimids, resulted in the rise of Șalāh al-Dīn's prominence - this battle proved Șalāh al-Dīn's bravery and strength. Moreover, the histories of Syria and Egypt, in the words of Lapidus, "would be joined until the nineteenth century" as a result. ${ }^{62}$

Nūr al-Dīn Maḥmūd ibn Zangī ibn Āqsunqūr, ruler of Syria, Mesopotamia, and Egypt, died of a heart attack on Wednesday 11 shawwāl 569/15 May 1174 and was buried in the citadel at Damascus but was later transferred to the madrasa that he had founded near the Osier-workers' market (sūq al-khawāsinn) in Damascus. ${ }^{63} \mathrm{Nūr}$ al-Dīn, as a mujāhid, earned his reputation as the liberator of Muslim territories, especially Syria, from the Franks, which also led toward the reunification of Syria and Egypt. His admirers often speak of his high morals, piousness, stature as a true Sunnī Muslim and theologian, and rather zealous embrace of jibād against the Franks.

Riley-Smith, The Oxford History of the Crusades, 227.

See Abū l-Qāsim Shihāb al-Dīn 'Abd al-Rahmān ibn Ismāc̄il Abū Shāma al-Maqdisī, 'Uyūn al-rawdatayn fì akhbār al-dawlatayn al-Nūriyya wa-l-Salāḅiyya (ed. Ibrāhīm al-Zaybaq; Beirut: Mu’assasat al-Risāla, 1997), I, 407-414 (hereafter cited as 'Uyūn al-rawdatayn).

62 Lapidus, A History of Islamic Societies, 290.

63 Ibn al-Athīr, al-Kāmil fì l-tārīkh, IX, 393; see also Gabrieli, The Arab Historians of the Crusades, 41-42. 
'Imād al-Dīn al-Ișfahānī, the littérateur, historian, and administrator, portrays Nūr al-Dīn's role in the jihād as:

The one who reinstalled Islam and the sharī'a in al-Shäm (area of Syria recovered from the crusaders), after kufr (unbelief) had replaced it. He fortified the borders with the Franks, built schools (religious schools), established khānqāhs (a religious building dedicated to Sufis) for the Sufi, restored the walls of the cities ... After all, Nūr al-Dīn was the leader who returned Egypt to Islam (Sunnī) and established a new administration there! ${ }^{64}$

Indeed, Nūr al-Dīn fought against a variety of opponents, as Hillenbrand remarks: "his own Sunni Muslim political rivals in Syria, Ismā $c_{1} \mid \bar{l}$ Shīcite and other factions in Egypt, Byzantine ... and last but not least the Franks." Moreover, "it is he [Nūr al-Dīn], rather than Ṣalāh al-Dīn," Hillenbrand adds, "whose reputation was most glorious in the succeeding centuries in the Islamic world." " 55 One of the remarkable political achievements of Nūr al-Dīn, according to scholars, was "the overthrow of the Fātimid Caliphate in Egypt, and the restoration of Sunnism there" which was successfully accomplished under Șalāh al-Dīn after the death of the Fạțimid Caliph, Abū Muhammad 'Abd Allāh al-'Ạdid li-dīn Allāh, the last of the Egyptian Caliphs, in $565 / 1171,{ }^{66}$ thus ending more than 200 years of Fātimid rule in Egypt. Furthermore, in the words of Lapidus, Nūr al-Dīn's reign ushered in a renaissance of "a new Muslim communal and religious spirit, frankly anti-Christian and opposed to the Crusader presence." ${ }^{67}$ Summarizing Nūr al-Dīn's efforts, Elisseef N. discusses four main touchstones on which his system of belief was based: "the revival of $j i h \bar{a} d$, the liberation of Jerusalem, the re-

64 Abū Shāma al-Maqdisī, 'Uyūn al-rawdatayn, I, 50-51.

65 Hillenbrand, Crusades: Islamic Perspective, 118.

66 Dajani-Shakeel, "Perceptions of the Counter-Crusade," 58; Hillenbrand, Crusades: Islamic Perspective, 118; "Saladin, acting as Nūr al-Dīn's lieutenant, established himself as secular leader, or vizier, in 1169. Two years later, on September 10, 1171, Saladin reestablished Sunnī prayers in Cairo and thus brought the Fātimid Caliphate to an end. Syria and Egypt were now united under the theoretical leadership of the 'Abbāsid caliphs. With Nūr al-Dīn at the military helm, the Turks seemed ready to eliminate the Franks from the Middle East;" on this, see Jay Rubenstein, "Saladin and the Problem of the Counter-Crusade in the Middle Ages," Historically Speaking 13 (2012), 2-5.

67 Lapidus, A History of Islamic Societies, 290. 
establishment of the political unity of Islam, and the diffusion of Sunnī orthodoxy." 68

Ṣalāh al-Dīn Yūsuf ibn Ayyūbī, ${ }^{69}$ a Tikrit-born Kurd admired in the West as Saladin, was undoubtedly one of the best Muslim warriors and the first non-Fātimid independent ruler in Egypt in almost two centuries. He is known in the annals of the History as the first Sultan of the vast Islamic lands - Egypt and Greater Syria (what is now Syria, Lebanon, and Palestine). He continued the policy of his master, Nūr al-Dīn, of reuniting and consolidating the Muslim territories, developing an Islamic front in preparation for $j i h \bar{a} d$. Like his master, Șalāh al-Dīn and his family enthusiastically participated in the Sunnī Revival across Syria and Egypt. It is often asked why Nūr al-Dīn and Ṣalāḥ al-Dīn attacked and abolished the Fāṭimid Empire. The reasons were probably evident in the fact that the Fātimids often made alliances with the Franks against the Sunnī Muslims whom they viewed as the supplanters of the legitimate authority since the early Islamic century. Șalāh al-Dīn thought it necessary to take hold of the Egypt and build a massive disciplined and skilled army with unwavering devotion to the idea of jiba $\bar{a} d$ to retake all the lands occupied by the Crusaders, especially Jerusalem.

Like his predecessor, Șalāḥ al-Dīn faced various challenges to realizing his long cherished goal, the re-conquest of the Jerusalem. His unwavering devotion to jiha $\bar{a} d$ and great passion for Jerusalem can be substantiated from his own statement: "And with God's help, we will be able to release, from captivity, the mosque [al-Aqșā] from

As quoted in 'Abd al-Raḥmān Azzām, Saladin (Harlow, England \& New York: Pearson Longman, 2009), 43.

69 For the career of Șalāh al-Dīn, or "Saladin," see among others, H. A. R. Gibb, The Life of Saladin (Oxford: Clarendon Press, 1973); Bahā’ al-Dīn Yūsuf ibn Rāfi` Ibn Shaddād, The Rare and Excellent History of Saladin or al-Nawādir al-șultāniyya wa-l-mahāsin al-Yūsufiyya by Bahā' al-Dīn ibn Shaddād (translated by D. S. Richards; Aldershot, England \& Burlington, VT: Ashgate Publishing, 2002); Stanley Lane-Poole, Saladin and the Fall of the Kingdom of Jerusalem (New York \& London: G. P. Putman's Sons, 1906); Malcolm Cameron Lyons and D. E. P. Jackson, Saladin: The Politics of Holy War (Cambridge: Cambridge University Press, 1977); David Nicolle, Saladin: Leadership, Strategy, Conflict (Oxford \& Long Island City, NY: Osprey Publishing, 2011); P. H. Newby, Saladin in His Time (New York: Dorset Press, 1992); Azzām, Saladin. 
which God has lifted His Messenger to the Heavens." ${ }^{70}$ However, he soon became the independent ruler of Egypt but was still a lieutenant of Nūr al-Dīn, and in favor and "recognition of the 'Abbāsid Caliph as the highest spiritual authority, and as the only symbol of Islamic unity," there emerged many rebellions/plots against him because the ousted Fāțimids resented him as a foreigner and a usurper of their rights. ${ }^{71}$ In Syria, after the death of Nūr al-Dīn in 1174, the situation worsened. The death of a ruler always led to a succession struggle, and this was coupled with attacks from the Crusaders. There were, however, uneasy relations between Nūr al-Dīn and Șalāh al-Dīn after 1171 when Salāh al-Dīn become the ruler of Egypt. However, things changed quickly after Nūr al-Dīn's death in 1174; the situation was so grave that some scholars were compelled to write, "Had Nur al-Din lived then it would be fair to say that Saladin would have been relegated to a footnote in history." ${ }^{72}$

Following Nūr al-Dīn's death, Syria fell into a state of disarray; Franks, steeped in the politics of Syria, immediately captured some territories. Hence, for Șalāh al-Dīn to launch a massive campaign on both fronts - Syria and Egypt - against the Franks, it was necessary to put down the weak Muslim rulers who had surfaced to try to take power in Syria. It was also necessary to stop the Franks to protect Syria from falling into the hands of the Crusaders. Hence, he remained busy fighting fellow Muslims, though incessant wars against the Franks had to continue in order to keep them from taking further Muslim territories in Syria and Egypt. From 1171-1186, Șalāḥ al-Dīn employed a number of military and political measures to achieve his goal. As stated earlier, he restored the 'Abbāsid Caliph's authority,

70 Dajani-Shakeel, "Perceptions of the Counter-Crusade," 58.

71 On this see, 'Abd Allāh Nāsih 'Ulwān, Salab ad-Dīn al-Ayyubi (Saladin): Hero of Battle of Hattin, Liberator of Jerusalem from Crusaders (translated into English by Khalifa Ezzat Abu Zeid; $2^{\text {nd }}$ edn., Cairo: Dār al-Salām, 2004), 35-39; see also, Gibb, Life of Saladin, 8; Azzām, Saladin, 122.

72 Azzām, Saladin, 101; the main issue at stake was what to do about Egypt. As mentioned, Egypt was seen as important from a political and economic perspective. Nūr al-Dīn had made Damascus the center for his jihäd campaign, but Șalāḥ al-Dīn wanted to use the resources from Egypt for $j i h \bar{a} d$; their strategies might have been different, but the goal was same-conquering the occupied land of the Franks, especially Jerusalem; on this, see also, for example, Nicolle, Saladin, 13. 
reestablished Sunnī prayers in Cairo, fortified the Egyptian frontier with the Franks, and connected Syria with Egypt thereby making the route safe for Muslim trade and the pilgrimage to Mecca that Franks often attempted to disrupt. ${ }^{73}$

However, Western historians argue that Șalāh al-Dīn's quest for Jerusalem only emerged when, quoting his biographer Ibn Shaddād, he received a vision following his recovery from illness just two months before his conquest of Jerusalem. Prior to that, his purpose, they argue, was to seize control of as much of Nūr al-Dīn's territories as possible. ${ }^{74}$ This underestimates Șalāh al-Dīn's long years of religious zeal in propagating jiba $\bar{a}$ and reuniting the embattled lands and people, part of which was the important recovery of the Latin Kingdom of Jerusalem. Dajani-Shakeel also disagrees with this argument, terming it "a misreading of history." She clarifies and adds that "Interruptions in Salāh al-Dīn's progress towards achieving this goal [of capturing Jerusalem]" have led some historians "to minimize his quest for the recovery of the city." " Șalāh al-Dīn's dedication to $j i h \bar{a} d$ can be judged from the following statement made soon after he established Sunnī authority in Egypt. Following Islamic principles, he led a number of attacks against the Franks and stated:

If the means for the recovery of Jerusalem are obstructed, and if the will of the Muslims for uprooting the kufr is not sheathed, then the roots of kufr will expand; its (the kufr) menace to the Muslims will increase, and we (the Muslims and their leaders) will be held responsible before God (for failing to check its expansion), and those who fail (to carry on the jih $\bar{a} d$ ) are sinful. ${ }^{76}$

73 "Reynald of Chatillon in the Red Sea, threatening the Holy Cities [Mecca and Madina], prompted Saladin to attack Reynald," see Hillenbrand, Crusades: Islamic Perspective, 172; Dajani-Shakeel, "Perceptions of the Counter-Crusade," 61

74 On this, see Rubenstein, "Saladin and the Problem of the Counter-Crusade in the Middle Ages," 3; Hillenbrand, Crusades: Islamic Perspective, 118; Peter Partner, God of Battles: Holy Wars of Christianity and Islam (Princeton, New Jersey: Princeton University Press, 1997), 93-94 (hereafter cited as God of Battles).

75 Hadia Dajani-Shakeel, "Some Medieval Accounts of Salah al-Din's Recovery of Jerusalem (al-Quds)," in Hisham Nashab (ed.), Studia Palaestina: Studies in bonour of Constantine K. Zurayk (Beirut: Beirut Institute for Palestine Studies, 1988); Retrieved from http://legacy.fordham.edu/halsall/med/salahdin.asp (hereafter as Dajani-Shakeel, al-Quds).

76 Dajani-Shakeel, "Perceptions of the Counter-Crusade," 62. 
Ṣalāh al-Dīn remained continuously committed to his jihād passion and harassed the Crusader enemies all along. He is reported to have said:

We focused on raiding the territories of the infidels (al-kuffar). Thus, not one year passed without our conducting a raid (against the Crusaders), by land or sea...until we have afflicted them with killing, capture and enslavement. We recovered some strongholds, which the people of Islam (the Muslims) have hardly frequented, ever since they were usurped from them.... Among these is a fortress in Aiyla, which the enemy had built in the Sea of India (reference to the Gulf of 'Aqaba at the Red Sea), and which leads to the two holy Muslim shrines (in Mecca and Medina), as well as to al-Yaman.... ${ }^{77}$

Although it appears that Șalāh al-Dīn's course of actions were incoherent and lacked a specific goal, an astute observer will appreciate that his strategies followed one another in a systematic and coherent way. Shakeel has broadly classified Șalāḥ al-Dīn's actions towards the recovery of Jerusalem: "the military, the demographic, and the ideological." ${ }^{78}$ One can easily detect that Șalāh al-Din envisioned a unified front comprising Egypt, Syria, Yemen, the Jazìra (Mesopotamia), and North Africa under his leadership to increase his manpower and, moved by jiha $\bar{a} d$ enthusiasm, to prepare for the recovery of Jerusalem.

He pursued a two-pronged policy of seeking to subvert Nūr alDin's dominions to subdue them after his death and of prosecuting the holy war against the Franks. He, like other rulers, also made alliances with the Franks to help accomplish his long-term policies. Eventually, in 1174, he took Damascus; in 1183, Aleppo; and in 1186, Mosul. In the following year, he launched a decisive attack and defeated the Franks at the Battle of Hațin in July 1187, which paved the way for the easy conquest of Jerusalem and thus brought an end to the Latin Kingdom of Jerusalem in October 1187, after ninety years of Christian occupation. ${ }^{79}$ From then on, Jerusalem remained under

\footnotetext{
77 As quoted in Dajani-Shakeel, "Perceptions of the Counter-Crusade," 60-61.

78 Dajani-Shakeel, al-Quds.

79 Partner, God of Battles, 93-94: Lapidus, A History of Islamic Societies, 194; Hillenbrand, Crusades: Islamic Perspective, 127; for Șalāh al-Dīn's specific steps in his course of actions towards the conquest and recovery of Jerusalem, see, for example, Dajani-Shakeel, al-Quds; Lane-Poole, Saladin and the Fall of the
} 
Muslim rule until 1917, except for a relatively short period from AD 1229 to 1238 (39). Șalāh al-Dīn earned the honorific title as the second liberator of Jerusalem after the Second Caliph of Islam, 'Umar ibn al-Khațtāb. 'Imād al-Dīn al-Ișfahānī (d. 1201) termed the victory in Jerusalem as the second hijra (immigration) of Islam to the "Holy House," accomplished through Șalāḥ al-Dīn. ${ }^{80}$ This implied the revival of Islam in Jerusalem. Similarly, Bahā' al-Dīn ibn Shaddād (d. 632/1234) defined the recovery as the "greatest victory." ${ }^{\prime 1}$ In the West, Șalāh al-Dīn is revered for his friendly treatment of Crusader prisoners of war, especially in contrast to what the Franks did to the Muslims during their savage conquest in 1099. Șalāh al-Dīn, being a "genuine religious leader," ${ }^{2}$ showered gifts and money on the Franks, especially the poor Christian families, for which he is greatly revered as "the flower of chivalry." ${ }^{83}$ Such was the charity that Șalāh al-Dīn bestowed on the poor that Lane-Poole has recorded the long passage of the Christian chronicler Ernoul:

Then I shall tell you ... of the great courtesy which Saladin showed to the wives and daughters of knights, who had fled to Jerusalem when their lords were killed or made prisoners in battle ... they assembled and went before Saladin crying mercy ... When Saladin saw them weeping, he had great compassion for them, and wept himself for pity ... And he gave them so much that they gave praise to God and publish abroad the kindness and honour which Saladin had done to them. ${ }^{84}$

In all, Gibb attributes Șalāh al-Dīn's successes not so much to his impressive personal military virtues, but instead states that his victories were due to his "possession of moral qualities which have little in common with those of a great general." 85

Kingdom of Jerusalem, 230.

80 Dajani-Shakeel, "Perceptions of the Counter-Crusade," 65.

81 Abū Shāma al-Maqdisī, 'Uyūn al-rawdatayn, III, 330.

82 Partner, God of Battles, 93-94.

83 Lane-Poole eulogizes Șalāh al-Dīn with that title in his book. See Lane-Poole, Saladin and the Fall of the Kingdom of Jerusalem, 230.

84 Ibid., 232-233.

85 Gibb, Life of Saladin, 57. 


\section{Diplomatic Relations}

Șalāh al-Dīn's conquest of Jerusalem led Europe to launch one of its greatest Crusades, headed by three influential kings of Germany, France, and England. Richard the Lion-Heart, however, became particularly famous for his exceptional military and diplomatic skills that he ruthlessly exhibited during the crusade. There were many confrontations, directly or indirectly, between Șalāh al-Dīn and Richard, with the latter trying hard, but in vain, to recover the lost territories. The wave of conquests had thus reversed its course of action. The Muslim religious and ruling classes were now mobilized and unified with great religious zeal to thwart any onslaught from the Franks.

The Muslim response to the Third Crusade was also characterized by "diplomacy, negotiations, and flexibility." 86 Despite the West's continued attempts to regain what it had lost, the Third Crusade, in the words of Dajani-Shakeel, "remained confined militarily and geographically." ${ }^{\text {M7 }}$ Muslims successfully arrested the further advance of the Franks into their lands and continuously kept them in check. Eventually, to establish peace just a year before his death in $1193,{ }^{88}$ Ṣalā al-Din made a truce with Richard that allowed the Crusaders to retain the coastal line along the Mediterranean, and thus, once and for all, the Crusaders abandoned their quest for Jerusalem. ${ }^{89}$ Enacting truces and entering into alliances with the Franks were indispensable and a common feature of most of Muslim rulers, including Șalāḥ al-Dīn.

86 Dajani-Shakeel, "Perceptions of the Counter-Crusade," 66; Dajani-Shakeel has devoted a full chapter to discussing various aspects of the relations between Muslims and Franks during the Crusades; see, Hadia Dajani-Shakeel, "Diplomatic Relations Between Muslim and Frankish Rulers 1097-1153 AD.," in Maya Shatzmiller (ed.), Crusaders and Muslims in Twelfth-Century Syria (Leiden \& New York: Brill, 1993), 201.

87 Dajani-Shakeel, "Perceptions of the Counter-Crusade," 66.

88 "This was the only instance of a King's death that was truly mourned by the people," Gibb, Life of Saladin, 76.

89 On 2 September 1192, a formal three-year peace agreement was established between the Christians and Muslims. Șalāh al-Dīn agreed to keep the road to Jerusalem open for Christian pilgrims. See Nicolle, Saladin, 43. 
The politics of alliances and truces had a conspicuous impact on the social and economic lives of the Muslims and Western Christians; intercultural exchanges and social relations developed that remained a somewhat ignored subject of the Crusades and should be highlighted and appreciated: Muslims and Franks engaged in cultural, economic and information exchanges. The Franks were one of the main actors in the Levant with whom the Muslims had trade and commercial links despite the 'official' state of war. This trade would increase whenever peace treaties were enacted, particularly after the famous truce agreement between Richard I and Șalāh al-Dīn. Diplomatic relations would often foster civilian contacts. This did not mean that such contacts were always genteel, "but it does mean that Frankish-Muslim relations were far richer than the strictly military narrative would allow." ${ }^{00}$ The commercial interaction implies cultural interaction, visible in the form of language. Many commercial terms of Arabic origin entered into various Romance languages: words for "custom," such as douane and aduana, all trace their roots to the Arabic dīwān; other examples include the words cheque from sakk (a letter of credit) and tariff from $t a^{\prime}$ riff (a notification). ${ }^{91}$

Similarly, there was considerable transmission of learning from the Muslims to the Franks. Scientific and religious books were translated from Arabic into Latin, mostly from Spain and Sicily, and these formed the base for later significant developments in European intellectual culture. Muslims in turn also learned some tactics in war technology from the Franks..$^{92}$ It is reported that the social interactions between the opposing communities were at the highest level, resulting in the exchange of "physicians, food, gifts and services, as well as the exchange of visits among the commanders." ${ }^{33}$

This relationship continued to flourish alongside the 'state of war' under the Șalāh al-Dīn's family, the Ayyūbids (who ruled Egypt to 1250 and Syria to 1260). However, the Mamlūks (slave regiments), who overthrew the Ayyūbids, ultimately destroyed the last Crusader state, Acre, in 1291 and brought an end to Crusader Christian

\footnotetext{
90 Paul M. Cobb, The Race for Paradise: An Islamic History of the Crusades (New York: Oxford University Press, 2014), 170.

91 Ibid., 172-173.

92 Christie, Muslims and Crusades, 65-67, 73-76.

93 Dajani-Shakeel, "Perceptions of the Counter-Crusade," 66.
} 
presence in the Levant. Mamlūks, such as Ṣalāh al-Dīn, regarded the struggle against the invaders as the most pressing form of $j i h \bar{a} d .{ }^{94}$ Thereby, the Muslim sultans made tangible the dreams of al-Sulami (who first attempted to mobilize the Muslim rulers with his intellectual capability a century earlier). ${ }^{95}$ In this way, al-Sulamī's message of political unity and spiritual purity was translated into a pragmatic reality by practicing the ideal of jiba $\bar{a} d$ - a touchstone by which Muslim rulers were judged. ${ }^{96}$ Jerusalem, in its way, played an important role in this renewal of jiha $\bar{a} d$ thought.

\section{Conclusion}

What emerges from the above discussion is that the Muslim response to the Crusades was initially fragmented and disorganized. Muslim intellectuals and religious figures played an important role in expelling the Franks from the Levant. During the course of action, the jiba $\bar{a}$ ideal was aptly exploited to build strong opposition to the enemy. Equally important is the place and role of Jerusalem, which remained a touchstone for any ruler in his jih $\bar{a} d$ campaign against the Crusaders. This study analyzed the two significant aspects of the response in the form of the production of a particular genre of literature and the birth of the Muslim-Christian relationship during the Crusades. The paper supported deeper exploration and analysis of the Muslim, particularly through Muslim sources, in order to uncover many fruitful and constructive medieval aspects, especially intercultural relationships that will help diminish the East-West discontent, distrust, and alienation.

\section{ACKNOWLEDGMENTS}

The author gratefully acknowledges the financial support of UGC, New Delhi, without which this research would not have been possible.

\footnotetext{
94 Nikolas Jaspert, The Crusades (trans. Phyllis G. Jestice; London \& New York: Routledge, 2003), 77.

95 Rubenstein, "Saladin and the Problem of the Counter-Crusade in the Middle Ages," 5.

96 Partner, God of Battles, 93-94.
} 


\section{REFERENCES}

Abū Shāma al-Maqdisī, Abū 1-Qāsim Shihāb al-Dīn 'Abd al-Raḥmān ibn Ismā'̄̄l, 'Uyūn al-rawdatayn fì akbbār al-dawlatayn al-Nūriyya wa-lȘalāhiyya, 5 vols., (ed. Ibrāhīm al-Zaybaq; Beirut: Mu’assasat al-Risāla, 1997).

Akbar, M. J., The Shade of Swords: Jihad and the Conflict between Islam and Christianity (London \& New York: Routledge, 2002).

Atiya, Azīz Suryal, Crusade, Commerce, and Culture (Bloomington: Indiana University Press, 1962).

Azzām, 'Abd al-Raḥmān, Saladin (Harlow, England \& New York: Pearson Longman, 2009).

al-Bayhaqī, Abū Bakr Aḥmad ibn al-Husayn ibn 'Alī, Shu'ab al-īmān, 14 vols., (Riyadh: Maktabat al-Rushd, 2003).

Bonner, Michael, Jihād in Islamic History: Doctrines and Practices (Princeton \& Oxford: Princeton University Press, 2006).

al-Bukhārī, al-Imām Abū 'Abd Allāh Muhammad ibn Ismācīl, Șaḥị̣ alBukhārī, 9 vols., (translated into English by Muḥammad Mụ̣sin Khān; Riyadh: Dār al-Salām, 1997).

Christie, Niall, The Book of the Jihād of 'Ali ibn Tabir al-Sulami (d. 1106): Text, Translation and Commentary (Farnham, England: Ashgate Publishing, 2015).

Christie, Niall, Muslims and Crusades: Christianity's Wars in the Middle East 1095-1382: From the Islamic Sources (New York, NY: Routledge, 2014).

Cobb, Paul M., The Race for Paradise: An Islamic History of the Crusades (New York: Oxford University Press, 2014).

Dajani-Shakeel, Hadia, "A Reassessment of Some Medieval and Modern Perceptions of the Counter-Crusade," in Hadia Dajani-Shakeel and Ronald A. Messier (eds.), The Jihād and Its Times: Dedicated to Andrew Stefan Ehrenkreutz (Ann Arbor: University of Michigan, Center for Near Eastern and North African Studies, 1991), 41-70.

Dajani-Shakeel, Hadia, "Diplomatic Relations between Muslim and Frankish Rulers 1097-1153 A.D.," in Maya Shatzmiller (ed.), Crusaders and Muslims in Twelfth-Century Syria (Leiden: E. J. Brill, 1993), 190-215.

Dajani-Shakeel, Hadia, "Some Medieval Accounts of Salah al-Din's Recovery of Jerusalem (Al-Quds)," in Hisham Nashab (ed.), Studia Palaestina: Studies in bonour of Constantine K. Zurayk (Beirut: Beirut Institute for Palestine Studies, 1988), 83-113, retrieved from http://legacy.fordham.edu/halsall/med/salahdin.asp. 
Elad, Amikam, Medieval Jerusalem and Islamic Worship: Holy Places, Ceremonies, Pilgrimage ( ${ }^{\text {nd }}$ edn., Leiden: Brill, 1999).

Foss, Michael, People of the First Crusade: The Truth about the ChristianMuslim War Revealed (New York: Arcade Publishing, 1997).

Gabrieli, Francesco, The Arab Historians of the Crusades (translated from Italian into English by E. J. Costello; Abingdon \& New York: Routledge, 2010).

Gibb, H. A. R., The Life of Saladin (Oxford: Clarendon Press, 1973).

Gil, Moshe, A History of Palestine, 634-1099 (Cambridge \& New York: Cambridge University Press, 1992).

Hillenbrand, Carole, The Crusades: Islamic Perspective (Edinburgh: Edinburgh University Press, 1999).

Ibn al-Athīr, Abū l-Ḥasan 'Izz al-Dīn 'Alī ibn Muhammad ibn Muḥammad alShaybānī al-Jazarī, al-Kāmil fì l-tārīkh, 13 vols., (ed. C. J. Tornberg; Beirut: Dār Ṣādir, 1965-1967).

Ibn al-Athīr, Abū l-Ḥasan 'Izz al-Dīn 'Alī ibn Muḥammad ibn Muḥammad alShaybānī al-Jazarī, al-Tārīkh al-bāhir fì l-Dawla al-Atābakiyya bi-lMawșil (ed. 'Abd al-Qādir Aḥmad Ṭulaymāt; Cairo: Dār al-Kutub alHaditha, 1963).

Ibn al-Athīr, Abū l-Ḥasan 'Izz al-Dīn 'Alī ibn Muhammad ibn Muhammad alShaybānī al-Jazarī, The Chronicle of Ibn Al-Athīr for the Crusading Period from al-Kamil fi'l-Ta'rikh, Part I: The Years 491-541/10971146: The Coming of the Franks and the Muslim Response (translated by D. S. Richards; Farnham, England: Ashgate, 2010).

Ibn 'Asākir, Abū l-Qāsim 'Alī ibn al-Ḥasan, Tārīkh Madīnat Dimashq, 80 vols., (ed. 'Umar ibn Gharāma al-'Amrawī and 'Alī Shīrīi; Beirut: Dār al-Fikr, 1995-2001).

Ibn Kathīr, Abū 1-Fidā' 'Imād al-Dīn Ismācịl ibn Shihāb al-Dīn 'Umar, Tafsìr Ibn Kathīr-Abridged Volume 5, Surah Hud to Surat Al-Isra', Verse 38, $3^{\text {rd }}$ edn., Riyadh, Houston, New York \& Lahore: Darussalam Publishers; 2003).

Ibn Shaddād, Bahā’ al-Dīn Yūsuf ibn Rāfí, The Rare and Excellent History of Saladin or al-Nawādir al-șultāniyya wa-l-maḥāsin al-Yüsufiyya by Bahā' al-Dīn ibn Shaddād (translated by D. S. Richards; Aldershot, England \& Burlington, VT: Ashgate Publishing, 2002).

Jaspert, Nikolas. The Crusades (translated by Phyllis G. Jestice; London \& New York: Routledge, 2003).

Kelsay, John, Arguing the Just War in Islam (Cambridge: Harvard University Press, 2007).

Lambden, Stephen N., "Islamic Faḍā’il ["Excellences"] and associated 
literatures," available at

http://www.hurqalya.pwp.blueyonder.co.uk/BIBLIOGRAPHY-

HYP/06-FUTUH\%20\&\%20FADA\%27IL/Fada\%27il-QUDS.htm\#_ftn1

(accessed June 2, 2015).

Lane-Poole, Stanley, Saladin and the Fall of the Kingdom of Jerusalem (New York \& London: G. P. Putman's Sons, 1906).

Lapidus, Ira M., A History of Islamic Societies ( ${ }^{\text {nd }}$ edn., Cambridge \& New York: Cambridge University Press, 2002).

Lyons, Cameron, and D. E. P. Jackson, Saladin: The Politics of Holy War (Cambridge: Cambridge University Press, 1977).

Mourad, Suleiman A., and James E. Lindsay (eds.), The Intensification and Reorientation of Sunni Jihad Ideology in the Crusader Period 3 (Leiden: Brill, 2013).

Muslim, Abū 1-Husayn Muslim ibn al-Hajjāj al-Qushayrī, Saḥ̄ḥ Muslim, 7 vols., (translated into English by Nașīr al-Dīn al-Khaț̣āb; Riyadh: Dār al-Salām, 2007).

Newby, P. H., Saladin in His Time (New York: Dorset Press, 1992).

Nicolle, David, Saladin: Leadership, Strategy, Conflict (Oxford \& Long Island City, NY: Osprey Publishing, 2011).

Partner, Peter. God of Battles: Holy Wars of Christianity and Islam (Princeton, New Jersey: Princeton University Press, 1997).

Reiter, Yitzhak, and Marwan Abu Khalaf, "Jerusalem's Religious Significance: Jerusalem in the faiths of Judaism, Christianity and Islam," PalestineIsrael Journal, 8/1 (2001), available at http://www.pij.org/details.php?id=169.

Riley-Smith, Jonathan (ed.), The Oxford History of the Crusades (New York: Oxford University Press, 1999).

Rubenstein, Jay, "Saladin and the Problem of the Counter-Crusade in the Middle Ages," Historically Speaking 13 (2012), 2-5.

Sivan, Emmanuel, L'Islamet la croisade: Idéologie et propagandedans les réactionsmusulmanes aux croisades (Paris: Librairie d'Amérique et d'Orient, 1968).

Thomas, David, and Alex Mallet (eds.), Christian-Muslim Relations: A Bibliographical History, (1050-1200) volume 3 (Leiden: Brill, 2011).

al-Tirmidhī, al-Imām al-Hāfiẓ Abū ‘̄̄sā Muhammad ibn ‘̄̄sā, Jāmi`Tirmidhì, 6 vols., (translated into English by Abū Khalīl; Riyadh: Dār al-Salām, 2007).

'Ulwān, 'Abd Allāh Nāsih, Salah ad-Dīn al-Ayyubi (Saladin): Hero of Battle of Hattin, Liberator of Jerusalem from Crusaders (2 ${ }^{\text {nd }}$ edn., translated 
by Khalifa Ezzat Abu Zeid; Cairo: Dār al-Salām, 2004).

al-Wāsițī, Abū Bakr Muḥammad ibn Aḥmad, Faḍā'il al-Bayt al-muqaddas (ed. Isaac Hasson; Jerusalem: Dār Māghnis, 1979). 